\title{
Sejarah Perkembangan Islam di Turki
}

\author{
Fathur Rahman \\ Universitas Islam Negeri (UIN) Sunan Kalijaya Yogyakarta \\ father_2000@yahoo.com
}

Abstract: Over the hundreds of years, Islam have been growing rapidly in Turkey. Although the majority of its people are Muslims, in its development, Turkey became a republic with a secular democratic state system. In this paper will be reviewed the history of Islamic development in Turkey, including developments in the reform era that makes Turkey as it is today, the country that constructs Islam as a rational and scientific religion. The history of Turkey is divided into five periods. The first period, ie in 1299-1402, begins with the founding of the Ottoman empire. The Second Period, 1402-1566, is marked by royal restoration. The third period, 15661699, was marked by the Ottoman ability to defend its territory. The fourth period, the year 1699-1838, marked degan gradually subside of the kingdom then experience more progress. The fifth period, 1839-1922, was marked by a cultural revival and Turkey became a republic, and it was no longer a system of government based on empire, dynasty, or caliphate as it had been for centuries. Mustafa Kemal established Turkey as a secular modern state based on its disappointment with the previous Caliphate system. In the latter period also called the contemporary era, although acknowledged as a secular republic, the Turkish government supports the implementation of Friday prayers in the mosque as a form of social discipline. Likewise, fasting to build patience and patience, and 
paying zakat encourages one's generosity, the birth of Islamic parties; moral enforcement and social justice; banning polygamy and divorce decisions must be made in court; equal rights of women and men in education, work, and in politics-in 1934 women were given the right to be nominated in national elections.

Keywords: The History of Turkey, Ottoman Empire, Republic of Turkey, Mustafa Kemal, Secular, and Modern State.

\section{Pendahuluan}

Dalam sejarah perjalanan Islam, kondisi politik pemerintahan Islam mengalami pasang surut. Kadang maju kadang pula mundur, ${ }^{1}$ terutama pada masa pertengahan (1250-1800). Kemajuan-kemajuan yang dicapai pada periode klasik telah dihancurkan oleh tentara Mongol dan mengakibatkan runtuhnya Khilafah Abbasiyah di Baghdad. Runtuhnya kekhalifahan ini mengakibatkan kekuasaan politik Islam mengalami kemunduran secara drastis. Wilayah kekuasaan Islam terpecah-pecah dalam beberapa kerajaan-kerajaan kecil yang satu dengan lainnya saling memerangi. Beberapa peninggalan budaya dan peradaban Islam dihancurkan oleh tentara-tentara Mongol. Kondisi politik tersebut terus berlangsung hingga muncul dan berkembangnya tiga kerajaan besar yang di antaranya adalah kerajaan Turki Usmani (Ottoman). Kerajaan ini berhasil memajukan dan telah membangkitkan kembali semangat politik Islam, meskipun kemajuan-kemajuan tersebut tidaklah secemerlang dengan apa yang telah dicapai pada masa klasik.

Sejarah kerajaan Turki Usmani yang ditulis di dalam buku-buku tarikh Islam sering tidak mendapat porsi sebanyak yang diperoleh Dinasti Umayyah dan Abbasiyah. Melihat dari hasil budaya yang dipersembahkannya dipermukaan, Turki Usmani ini tidaklah bisa disamakan dengan

\footnotetext{
1 Ada tiga periode sejarah perjalanan Islam: (a) periode klasik [650-1250], (b) periode pertengahan [1250-1800 M], dan (c) periode modern [1800-sekarang]. Untuk penjelasan lebih lanjut lihat Harun Nasution, Islam Ditinjau dari Berbagai Aspeknya, Jilid I, Cet. ke-5 (Jakarta: UI-Press, 1985), 56-58.
} 
kedua Dinasti sebelumnya di atas, tetapi melihat peranannya sebagai benteng kekuatan Islam dalam menangkal ekspansi bangsa Eropa ke timur, maka dengan ini ia tidak bisa ditinggalkan begitu saja dalam kajian sejarah Islam. Sebab, Turki Usmani telah menunjukkan kehebatannya dalam menangkis serangan musuh. Serangan-serangan perluasan yang dilakukannya langsung menusuk ke wilayah penting, termasuk penaklukan Konstantinopel.

Demikianlah Turki Usmani tentang kerajaan Islam yang sampai kini pemerintahannya masih terwariskan, dan telah berubah menjadi negara Republik Turki atau Republic of Turkey, sebuah negeri tua yang menyimpan aneka ragam kemegahan karya budaya Islam masa silam, dan di masa itu perkembangan Islam cukup signifikan, dan terus berlanjut sampai sekarang, era kontermporer, yakni ketika bangsa Turki memasuki masa reformasi. Republik Turki yang dewasa ini ibukotanya Angkara, tercatat sebagai negara muslim yang tetap bertahan dijalur demokrasi dalam upaya menegakkan sebuah tatanan masyarakat Islami yang beradab. Negara Turki ini terletak di antara dua benua, yaitu Eropa I Utara dan Asia di Selatan. Wilayahya berbatasan dengan Yunani dan Bulgaria di Barat dan Utara, Azerbaijan di Timur Laut, Suriah dan Irak di Selatan serta Iran di Tenggara. Sebagai negara bekas jantung tempat salah satu kekhalifahan terbesar Islam, maka keterikatan Turki terhadap Islam berlangsung sangat kuat sebab mereka adalah bangsa terkemuka di dunia Islam selama beratus-ratus tahun lamanya. Ini berarti bahwa perkembangan Islam di Turki dalam perspektif sejarah sangat menarik untuk diuraikan dan dikaji lebih lanjut.

\section{Sejarah Awal Berdirinya Turki dan Perkembangannya}

Negara Turki yang kita kenal dewasa ini, Republik Turki, keberadaannya telah mengalami babakan sejarah yang cukup panjang, bermula dari berdirinya Kerajaan Turki Usmani pada periode pertengahan. Masa kemajuannya dihitung dari mulai digerakkannya ekspansi ke wilayah baru yang belum ditundukkan oleh pendahulu bangsa Turki. Keberhasilan mereka dalam memperluas wilayah kekuasaan serta ter- 
jadinya peristiwa-peristiwa penting merupakan suatu indikasi yang dapat dijadikan ukuran untuk menentukan kemajuan Turki dan sejarah perkembangan Islam di Turki.

Pendiri Turki adalah bangsa Turki sendiri dari kabilah Qayigh Oghus $^{2}$ salah satu anak suku Turki yang mendiami sebelah barat gurun Gobi, atau daerah Mongol dan daerah utara negeri Cina, yang dipimpin oleh Sulaiman. Dia mengajak anggota sukunya untuk menghindari serbuan bangsa Mongol yang menyerang dunia Islam yang berada di bawah kekuasaan Dinasti Khawarizm pada tahun 1219-1220. Sulaiman dan anggota sukunya kemudian pindah ke arah barat dan meminta perlindungan Jalaluddin, pemimpin terakhir Dinasti Khawarizm di Transoxiana. Jalaluddin menyuruh Sulaiman agar pergi kearah barat (Asia Kecil). Kemudian mereka menetap di sana dan pindah ke Syam dalam rangka menghindari serangan mongol.

Dalam usahanya pindah ke Syam itu, pemimpin orang-orang Turki mendapat kecelakaan. Mereka hanyut di sungai Efrat yang tiba-tiba pasang karena banjir besar pada tahun $1228 .^{3}$ Akhirnya mereka terbagi menjadi 2 kelompok, yang pertama ingin pulang ke negeri asalnya; dan yang kedua meneruskan perjalanannya ke Asia Kecil. Kelompok kedua ini berjumlah 400 kepala keluarga yang dipimpin oleh Ertugril (Erthogrol) ibn Sulaiman. Mereka mengabdikan dirinya dirinya kepada Sultan Alauddin II dari Dinasti Saljuk Rum yang pusat pemerintahannya di Kuniya, Anatolia Asia Kecil. Pada saat itu, Sultan Alauddin II sedang menghadapi bahaya peperangan dari bangsa Romawi yang mempunyai kekuasaan di Romawi Timur (Byzantium). Dengan bantuan dari bangsa Turki pimpinan Erthogrol, Sultan Alauddin II dapat mencapai kemenangan. Atas jasa baik tersebut Sultan menghadiahkan sebidang tanah yang perbatasan dengan Bizantium. Sejak itu Erthogrol terus membina wilayah barunya dan berusaha memperluas wilayahnya dengan merebut

2 John L. Esposito, The Oxford Encyclopedia of the Modern Islamic World, VI (Oxford: Oxford Univercity Press, 1995), 63; lihat juga Hasan Ibrahim Hasan, Tarikh al-Islami, IV (Kairo: Maktabah al-Nahdhah al-Misriyah, 1976), 324.

3 A. Syafiq Mughni, Sejarah Kebudayaan di Turki (Jakarta: Logos, 1997), 51. 
wilayah Byzantium. ${ }^{4}$

Pada tahun 1288 Erthogrol meninggal dunia, dan meninggalkan putranya yang bernama Usman, yang diperkirakan lahir pada $1258 \mathrm{M}$. Usman inilah yang ditunjuk oleh Erthogrol untuk meneruskan kepemimpinannya dan disetujui serta didukung oleh Sultan Saljuk pada saat itu. Nama 'Usman' inilah yang nanti diambil sebagai nama untuk Kerajaan Turki Usmani. Usman ini pula yang dianggap sebagai pendiri Dinasti Usmani. Sebagaimana ayahnya, Usman banyak berjasa kepada Sultan Alauddin II. Kemenangan-kemenangan dalam setiap pertempuran dan peperangan diraih oleh Usman. Dan berkat keberhasilannya maka benteng-benteng Bizantium yang berdekatan dengan Broessa dapat ditaklukkan. Keberhasilan Usman ini membuat Sultan Alauddin II semakin simpati dan banyak memberi hak istimewa pada Usman. Bahkan Usman diangkat menjadi gubernur dengan gelar Bey, dan namanya selalu disebut dalam doa setiap khutbah Jumat. ${ }^{5}$ Penyerangan bangsa Mongol pada tahun 1300 ke wilayah kekuasaan Saljuk Rum mengakibatkan terbunuhnya Sultan Saljuk tanpa meninggalkan putra sebagai pewaris kesultanan. ${ }^{6}$ Dalam keadaan kosong itulah, Usman memerdekakan wilayahnya dan bertahan terhadap serangan bangsa Mongol. Usman memproklamirkan kemerdekaan wilayahnya dengan nama Kesultanan Usmani.

Dengan jatuhnya jazirah Arab, maka imperium Turki Usmani mempunyai wilayah yang luas sekali, terbentang dari Budapest di pinggir sungai Thauna, sampai ke Aswan dekat hulu sungai Nil, dan dari sungai Efrat serta pedalaman Iran, sampai Babel-Mandeb di selatan jazirah Arab.7 Selama masa kesultanan Turki Usmani (1299-1942 M) sekitar 625 tahun berkuasa tidak kurang dari 38 Sultan. Dalam hal ini, Mughni

4 Siti Maryam, et.al., Sejarah Pearadaban Islam dari Masa Klasik hingga Modern (Yogyakarta: LESFI, 2002), 132.

5 Mughni, Sejarah Kebudayaan di Turki, 52.

6 Nasution, Islam Ditinjau dari Berbagai, 45.

7 Ahmad Syalabi, Mausu'ah at-Tarikh al-Islami (Kairo: Maktabah al-Nahdhat al-Mishriyah, t.t.), 660 . 
membagi sejarah perkembangan Turki Usmani menjadi lima periode, yaitu:

1. Periode pertama (1299-1402), yang dimulai dari berdirinya kerajaan, ekspansi pertama sampai kehancuran sementara oleh serangan timur yaitu dari pemerintahan Usman I sampai pemerintahan Bayazid.

2. Periode kedua (1402-1566), ditandai dengan restorasi kerajaan dan cepatnya pertumbuhan sampai ekspansinya yang terbesar. Dari masa Muhammad I sampai Sulaiman I.

3. Periode ketiga (1566-1699). Periode ini ditandai dengan kemampuan Usmani untuk mempertahankan wilayahnya. Sampai lepasnya Honggaria. Namun, kemunduran segera terjadi dari masa pemerintahan Salim II sampai Mustafa II.

4. Periode keempat (1699-1838). Periode ini ditandai degan berangsur-angsur surutnya kekuatan kerajaan dan pecahnya wilayah yang di tangan para penguasa wilayah, dari masa pemerintahan Ahmad III sampai Mahmud II.

5. Periode kelima (1839-1922). Periode ini ditandai dengan kebangkitan kultural dan administrasi dari negara di bawah pengaruh ide-ide Barat, dari masa pemerintahan Sultan A. Majid I sampai A Majid II. ${ }^{8}$

Pada periode yang terakhir ini, disebut sebagai periode era kontemporer di mana Turki menjadi negara republik, dan tidak lagi sistem pemerintahannya berdasar pada kerajaan, dinasti, atau kekhalifahan sebagaimana yang telah berlangsung berabad-abad lamanya.

\section{Sejarah Perkembangan Islam di Turki Masa Lalu}

Yang dimaksud sejarah perkembangan Islam di Turki masa lalu, adalah masa ketika Turki sebagai kerajaan Islam, atau masa-masa ketika Turki berada dalam periodesasi sejarah Islam, mulai periode pertama

\footnotetext{
${ }^{8}$ Mughni, Sejarah Kebudayaan di Turki, 54.
} 
tahun 1299-1942 M, sampai periode keempat tahun 1699-1838 sebagaimana yang telah disinggung di atas. Perkembangan Islam dalam masa-masa tersebut dapat dilihat antara lain pada segi perkembangan wilayah Islam. Ketika Usman sebagai pemimpin kerajaan Turki, dan sesaat setelah dia mengumumkan dirinya sebagai Padisyah al-Usman (raja besar keluarga Usman) pada tahun $1300 \mathrm{M}$, dia memulai mengembangkan wilayah Islam. ${ }^{9}$ Perluasan wilayah (ekspansi) para Sultan Usmani menjadi sebuah model. Hal ini berlangsung paling tidak sampai dengan masa pemerintahan Sulaiman I. Untuk mendukung hal itu, Orkhan membentuk pasukan tangguh yang dikenal dengan Inkisyariyah. Pasukan Inkisyariyah adalah tentara utama Dinasti Usmani yang terdiri dari bangsa Georgia dan Armenia yang baru masuk Islam. ${ }^{10}$ Ternyata, dengan pasukan tersebut seolah-olah Dinasti Usmani memiliki mesin perang yang paling kuat dan memberikan dorongan yang besar sekali bagi penaklukan negeri-negeri non Muslim. Maka, pada masa Orkhan I Kerajaan Turki Usmani dapat menaklukkan Azmir (Asia Kecil) pada tahun 1327, Thawasyani (1330), Uskandar (1338), Ankara (1354), dan Gholipolli (1356). Daerah-derah ini adalah bagian dunia Eropa yang pertama kali dapat dikuasai Kerajaan Usmani. ${ }^{11}$

Ekspansi yang lebih besar terjadi pada masa Murad I. Pada masa ini berhasil menaklukkan wilayah Balkan, Adrianopel (sekarang bernama Edirne, Turki), Macedonia, Sofia (ibukota Bulgaria), dan seluruh wilayah Yunani. Melihat kemenangan yang diraih oleh Murad I, kerajaan-kerajaan Kristen di Balkan dan Eropa timur menjadi murka. Mereka lalu menyusun kekuatan yang terdiri atas Hongaria, Bulgaria, Serbia, dan Walacia (Rumania), untuk menggempur Dinasti Usmani. Meskipun Murad I tewas dalam pertempuran tersebut, kemenangan tetap di pihak Dinasti Usmani. Ekspansi berikutnya dilanjutkan oleh putranya, Bayazid I.

9 Badri Yatim, Sejarah Peradaban Islam, Cet. VIII (Jakarta: Raja Grafindo Persada, 2002), 130.

${ }^{10}$ Hamka, Sejarah Umat Islam III (Jakarta: Bulan Bintang, 1981), 59.

${ }^{11}$ Yatim, Sejarah Peradaban Islam, 131. 
Sultan Bayazid yang naik tahta pada tahun 1389 M mendapat gelar Yaldirin atau Yaldrum yang berarti kilat, karena terkenal dengan serangan-serangannya yang cepat terhadap lawan-lawannya. Perluasan wilayah terus berlanjut dan dapat menguasai Salocia dan Morea. Bayazid I juga memperoleh kemenangan dalam Perang Salib di Nicapolas (1394). Ketika Sultan Bayazid sedang memusatkan perhatiannya untuk menghadapi musuh-musuhnya di Eropa, ia ditantang oleh musuh sesama Muslim yang datang dari Timur Lenk. Seorang raja keturunan bangsa Mongol yang telah memeluk Islam dan berpusat di Samarkhand. Timur Lank mendapat dukungan dari negeri-negeri di Asia Kecil yang tak mau tunduk kepada Bayazid. Akhirnya, terjadi pertempuran hebat di Ankara tahun 1402 M. Bayazid dengan kedua putranya, Musa dan Ergthogrol dikalahkan dan ditawan oleh Timur Lenk tahun 1402. Kekalahan ini membawa akibat buruk bagi Turki Usmani. Penguasa-penguasa di Asia Kecil melepaskan diri dari pemerintahan Usmani. Wilayah Serbia dan Bulgaria memproklamirkan kemerdekaannya. ${ }^{12}$

Puncak ekspansi terjadi pada masa Sultan Muhammad II yang dikenal dengan gelar al-Fatih (sang penakluk). Pada masanya dilakukan ekspansi kekuasaan Islam secara besar-besaran. Kota penting yang berhasil ditaklukannya adalah Konstantinopel (kota kerajaan Romawi Timur) yang ditaklukkan pada tahun 1453. setelah ditaklukkan, kota tersebut diubah namanya menjadi Istambul (tahta Islam). Kejatuhan Konstantinopel ke tangan Dinasti Usmani memudahkan tentara Usmani menaklukkan wilayah lainnya, seperi Serbia, Albania, dan Hongaria.

Sultan Muhammad meninggal pada tahun $1481 \mathrm{M}$ dan digantikan oleh putranya Bayazid II. Berbeda dengan ayahnya, Sultan Bayazid II lebih mementingkan kehidupan tasawuf dari pada penaklukkan wilayah dan perang. Hal ini menimbulkan perselisihan yang panjang dan pada akhirnya Sultan Bayazid II mengundurkan diri dari kursi kesultanan pada tahun 1512 M. Ia digantikan oleh putranya Salim I. Pada masa Sultan Salim I pemerintahan Usmani bertambah luas hingga menembus

\footnotetext{
${ }^{12}$ Mughni, Sejarah Kebudayaan di Turki, 59. Lihat juga Carl Brockkmann, History of the Islamic Peoples (London: Routledge \& Kegan Paul, 1982), 328.
} 
Afrika Utara, Syiria dapat ditaklukkan, dan Mesir yang diperintah oleh kaum Mamalik ditundukkan pada tahun 1517 M. Sejak masa ini para Sultan Usmani menyandang gelar khalifah. ${ }^{13}$

Menurut Syalabi, Sultan Salim I pernah meminta kepada khalifah Abbasiyah di Mesir agar menyerahkan kekhalifahan kepadanya, ketika ia menaklukkan Dinasti Mamalik. Pendapat lain menyebutkan bahwa gelar "khalifah" sebenarnya sudah digunakan oleh Sultan Murad (13591389 M) setelah ia berhasil menaklukkan Asia Kecil dan Eropa. Dari dua pendapat ini, Syalabi berkesimpulan bahwa para Sultan Kerajaan Usmani memang tidak perlu menunggu Khalifah Abbasiyah menye-rahkan gelar itu, karena jauh sebelum masa Kerajaan Usmani sudah ada tiga khalifah dalam satu masa. ${ }^{14}$ Pada abad ke $10 \mathrm{M}$ para penguasa Dinasti Fatimiyah di Mesir sudah memakai gelar khalifah. Tidak lama setelah itu, Abd al-Rahman al-Nashir di Spanyol menyatakan diri sebagai khalifah melanjutkan Dinasti Bani Umayyah di Damaskus, bahkan ia mencela para pendahulunya yang berkuasa di Spanyol yang meras cukup dengan gelar "Amir" saja. Karena itu, ada kemungkinan para penguasa Usmani memang sudah menggunakan gelar khalifah jauh sebelum mereka dapat menaklukkan Dinasti Mamalik, tempat pusat pemerintahan para Khalifah Abbasiyah. ${ }^{15}$

Dengan adanya berbagai ekspansi, menyebabkan ibukota Dinasti Usmani berpindah-pindah. Sebagai contoh, sebelum Usman I memimpin Dinasti Usmani, ia mengambil kota Sogud sebagai ibukota. Kemudian, setelah penguasa Dinasti Usmani dapat menaklukkan Broessa pada tahun 1317, maka Broessa dijadikan ibukota pemerintahan pada tahun 1326. Hal ini berlangsung sampai pemerintahan Murad I. Tetapi, kemudian Murad I yang menaklukkan kota Adrianopel ketika itu menjadikan kota Adrianopel sebagai ibukota pemerintahannya sampai ditaklukkannya konstantinopel oleh Muhammad II, yang kemudian diganti namanya menjadi Istambul sebagai ibukota pemerintahan yang terakhir.

\footnotetext{
${ }^{13}$ Brockkmann, History of the Islamic Peoples, 328-329.

${ }^{14}$ Syalabi, Mausu'ah al-Tarikh al-Islami, 34-35; Yatim, Sejarah Peradaban Islam, 133.

${ }^{15}$ Ibid.
} 
Ada beberapa faktor yang menyebabkan kesuksesan Dinasti Turki Usmani dalam perluasan wilayah Islam, dan antara lain (1) kemampuan orang-orang Turki dalam strategi perang terkombinasi dengan cita-cita memperoleh ghanimah, harta rampasan perang; (2) sifat dan karakter orang Turki yang selalu ingin maju dan tidak pernah diam, serta gaya hidupnya yang sederhana, sehingga memudahkan untuk tujuan penyerangan; (3) semangat jihad dan ingin mengembangkan Islam; (4) letak Istambul yang sangat strategis sebagai ibukota kerajaan juga sangat menunjang kesuksesan perluasan wilayah ke Eropa dan Asia. Istambul terletak antara dua benua dan dua selat (selat Bosphaoras dan selat Dardanala), dan pernah menjadi pusat kebudayaan dunia, baik kebudayaan Macedonia, kebudayaan Yunani maupun kebudayaan Romawi Timur; (5) kondisi kerajaan-kerajaan di sekitarnya yang kacau memudahkan Dinasti Usmani mengalahkannya.

Kemajuan dan perkembangan ekspansi Kerajaan Turki Usmani berlangsung dengan cepat, hal ini diikuti pula oleh kemajuan dalam bidang politik, terutama dalam hal mempertahankan eksistensinya sebagai negara besar. Hal ini berkaitan erat dengan sistem pemerintahan yang diterapkan para pemimpin dinasti ini. Selain itu, tradisi yang berlaku saat itu telah membentuk stratifikasi yang membedakan secara menyolok antara kelompok penguasa (small group of rulers) dan rakyat biasa (large mass). Penguasa yang begitu kuat itu bahkan memiliki keistimewaan, seperti (1) pengakuan dari bawahan untuk loyal pada sultan dan negara, (2) penerimaan dan pengamalan, serta sistem berpikir dalam bertindak dalam agama yang dianut merupakan kerangka yang integral, (3) pengetahuan dan amalan tentang sistem adat yang rumit. Yang terpenting adalah bahwa para pejabat dalam hal apapun tetap sebagai budak sultan. Tugas utama seluruh warga negara, baik pejabat maupun rakyat biasa adalah mengabdi untuk keunggulan Islam, melaksanakan hukum serta mempertahankan keutuhan imperium.

Sebagai struktur masyarakatnya sangat heterogen, Dinasti Usmani mempunyai kekuasaan yang menentukan nasib warga Timur Tengah dan Balkan, sampai pada tingkat yang luar biasa. Dinasti Usmani mendomi- 
nasi, mengendalikan, dan membentuk masyarakat yang dikuasainya. Salah satu konsep utama yang diterapkan oleh Usmani adalah perbedan antara askeri dan riaya, yakni antara kalangan elit penguasa dan yang dikuasai, elit pemerintah dan warga negara, antara tentara dan pedagang, antara petugas pemungut pajak dan pembayar pajak. Bahkan, untuk menjadi kelas penguasa seseorang harus dididik dalam kebahasaan dan tata cara yang khusus yang disebut dengan tata cara Usmani. Seseorang dapat menjadi elit Usmani melalui keturunan atau melalui pendidikan sekolah-sekolah kerajaan, kemiliteran, atau pendidikan keagamaan. ${ }^{16}$

Perkembangan lainnya adalah bahwa kerajaan Turki Usmani telah mampu menciptakan pasukan militer yang mampu mengubah Negara Turki menjadi mesin perang yang paling tangguh dan memberikan dorongan yang amat besar dalam penaklukan negeri-negeri non Muslim. Bangsa-bangsa non Turki dimasukkan sebagai anggota, bahkan anakanak Kristen diasramakan dan dibimbing dalam suasana Islam untuk dijadikan prajurit. Ketika terjadi konflik di tubuh militer, maka Orkhan mengadakan perombakan dan pembaharuan yang dimulai dari pemimpin-pemimpin personel militer. Program ini ternyata berhasil dengan terbentuknya kelompok militer baru yang disebut dengan pasukan Janissari atau Inkisyariyah. Pasukan inilah yang dapat mengubah negara Usmani menjadi mesin perang yang paling kuat dan memberikan dorongan kuat dalam penaklukan negeri non Muslim.

Selain itu, ada juga tentara feodal yang dikirim kepada pemerintah pusat; pasukan ini disebut dengan tentara atau kelompok militer Thaujiah. ${ }^{17}$ Keberhasilan ekspansi wilayah dibarengi dengan terciptanya jaringan pemerintah yang teratur. Di masa Sulaiman I, disusun sebuah kitab undang-undang (qonun) yang diberi nama Multaqa al-Abhur. Kitab ini menjadi pegangan hukum bagi kerajaan Turki Usmani sampai datangnya reformasi abad ke-19.

\footnotetext{
${ }^{16}$ Ira M. Lapidus, Sejarah Sosial Umat Islam (Jakarta: RajaGrafindo Persada, 1999), 496-497.

${ }^{17}$ Syalabi, Mausu'ah al-Tarikh al-Islami, 41.
} 
Pengelolaan administrasi pemerintah tidak hanya terbatas sampai ketingkat propinsi, tetapi selanjutnya diefektifkan dengan membentuk daerah-daerah tingkat II yang dikepalai oleh masing-masing kepala daerah (sanjaks). Di tingkat pusat di samping ada Sultan ada juga grand vizier (perdana menteri) yang dibantu oleh beberapa pembantu, di antaranya para ulama yang berfungsi sebagai lembaga pemberi fatwa atau dewan pertimbangan. ${ }^{18}$

Sebuah administrasi birokratik sangat diperlukan dalam pengkajian militer budak. Orkhan (1324-1360) melantik seorang wazir untuk menangani administrasi dan kemiliteran pusat dan mengangkat sejumlah gubernur sipil untuk sejumlah provinsi yang ditaklukkan. Kepala-kepala jabatan disatukan dalam sebuah dewan kerajaan. Lantaran Dinasti Usmani semakin meluas, beberapa provinsi yang semula merupakan daerah jajahan yang harus menyerahkan upeti digabungkan menjadi sebuah sistem administrasi. Unit provinsial yang terbesar dinamakan baylerbayliks, dibagi menjadi sanjak-bayliks dan selanjutnya dibagi-bagi menjadi timarliks, distrik tersebut diserahkan kepada pejabat-pejabat militer sebagai pengganti gaji mereka. Pada abad ke-16, term vali telah menggantikan baylerbayliks dengan pengertian seorang gubernur, dan istilah eyelet digunakan dengan arti propinsi di Eropa, yakni Rumania dan Transilvania, Krimea, dan beberapa distrik di Anotalia yang berada dalam pengawasan masyarakat Kurdi dan Turki tetap berlangsung sebagai semi provinsi mereka yang wajib menyerahkan upeti. ${ }^{19}$

Selanjutnya perkembangan dalam bidang pendidikan, Dinasti Turki Usmani mengantarkan pada pengorganisasian sebuah sistem pendidikan madrasah yang tersebar luas. Madrasah Usmani pertama didirikan di Izmir pada tahun 1331, ketika itu sejumlah ulama didatangkan dari Iran dan Mesir untuk mengembangkan pengajaran Muslim di beberapa teritorial baru. ${ }^{20}$ Tapi hal ini tidak begitu berkembang, karena Turki Usmani lebih memfokuskan kegiatan mereka dalam bidang kemiliteran, sehingga

\footnotetext{
${ }^{18}$ Ibid., 34.

${ }^{19}$ Lapidus, Sejarah Sosial Umat, 488-489.

${ }^{20}$ Ibid., 499.
} 
dalam khazanah intelektual Islam kita tidak menjumpai ilmuwan terkemuka dari Turki Usmani.

Dalam bidang ilmu pengetahuan, memang kerajaan Turki Usmani tidak menghasilkan karya-karya dan penelitian-penelitian ilmiah seperti di masa Daulah Abbasiyah. Kajian-kajian ilmu keagamaan, seperti fikih, ilmu kalam, tafsir dan Hadis boleh dikatakan tidak mengalami perkembangan yang berarti. Ulama hanya suka menulis buku dalam bentuk syarah (penjelasan) dan hasyiyah (catatan pinggir) terhadap karya-karya klasik yang telah ada. Namun, dalam bidang seni arsitektur, Turki Usmani banyak meninggalkan karya-karya agung berupa bangunan yang indah, seperti Masjid Jami’ Muhammad al-Fatih, Masjid Agung Sulaiman dan Masjid Abu Ayyub al-Anshary dan masjid yang dulu asalnya dari Gereja Aya Sophia. Masjid tersebut dihiasi dengan kaligrafi oleh Musa Azam. ${ }^{21}$ Pada masa Sulaiman, di kota-kota besar lainnya banyak dibangun masjid, sekolah rumah sakit, gedung, makam, jembatan, saluran air, villa, dan pemandian umum. Karena Turki mengusai beberapa kota pelabuhan utama, seperti pelabuhan-pelabuhan sepanjang Laut Tengah (Afrika Utara), pelabuhan Laut Merah, Teluk Persia, pelabuhan di Siria (pantai Libanon sekarang), pantai Asia Kecil, dan yang paling strategis adalah pelabuhan Internasional Konstantinopel yang menjadi penghubung Timur dan Barat waktu itu, maka Turki menjadi penyelenggara perdagangan, pemungut pajak (cukai) pelabuhan yang menjadi sumber keuangan yang besar bagi Turki.

Keberhasilan Turki Usmani dalam memperluas kekuasaan dan penataan politik yang rapi, berimplikasi pada kemajuan sosial ekonomi Negara; tercatat beberapa kota industri yang ada pada waktu itu, antara lain (a) Mesir yang memperoleh produksi kain sutra dan katun, (b) Anatoli memproduksi bahan tekstil dan wilayah pertanian yang subur. Kota Anatoli merupakan kota perdagangan yang penting di rute timur dalam perindustrian dalam hasil industri dan pertanian di Istambul, Polandia, dan Rusia. Para pedagang dari dalam maupun dari luar negeri berdatangan sehingga wilayah Turki menjadi pusat perdagangan dunia pada saat

${ }^{21}$ Ibid. 
itu. ${ }^{22}$ Selain dari sumber perdagangan, Turki Usmani memiliki sumber keuangan negara yang sangat besar, yaitu dari harta rampasan perang, upeti tanda penaklukkan negara-negara yang ditundukkan, serta dari orang-orang zhimmi.

Pada akhir kekuasaan Sulaiman al-Qanuni I Kerajaan Turki Usmani berada di tengah-tengah dua kekuatan monarki Austria di Eropa dan Kerajaan Syafawi di Asia. Setelah wafatnya Sulaiman I dan digantikan oleh Salim II, Kerajaan Usmani semakin melemah. Pengganti kepemimpinan ternyata tidak mampu menghadapi kondisi tersebut. Pada awal abad ke-19 para sultan tidak mampu mengontol wilayah kekuasaannya. Melemahnya militer Turki Usmani berakibat munculnya pemberontakan-pemberontakan di beberapa wilayah kekuasaan Turki Ustmani. Beberapa wilayah berangsur-angsur mulai memisahkan diri dan mendirikan pemerintah yang otonom.

Di Mesir, kelemahan Kerajaan Turki Usmani membuat Mamalik bangkit kembali. Di bawah kepemimpinan Ali Bey, pada tahun $1770 \mathrm{M}$ Mamalik kembali berkuasa di Mesir sampai datang Napoleon Bonaparte dari Perancis tahun $1798 \mathrm{M}^{23}$ Demikian pula pemberontakan-pemberontakan yang terjadi di Lebanon dan Syiria, sehingga kerajaan Turki Usmani mengalami kemunduruan, bukan saja wilayah-wilayah yang tidak beragama Islam, tetapi juga di wilayah yang berpenduduk Muslim. Demikian seterusnya sampai Turki memasuki masa reformasi, masa modern, era kontemporer, di mana Turki mulai lagi bangkit dengan sistem pemerintahan yang baru, yakni sistem demokrasi dalam bentuk negara Republik Turki.

\section{Sejarah Perkembangan Islam di Turki Masa Reiormasi}

Kelahiran Republik Turki yang diproklamirkan oleh Mustafa Kemal pada 29 Oktober 1923 yang ditandai dengan beralihnya Turki ke masa

\footnotetext{
${ }^{22}$ Ibid., 498.

${ }^{23}$ Hasan Ibrahim Hasan, Mausu'at al-Tarikh al-Islami V (Kairo: Maktabah al-Nahdhah al-Misriyah, 1967), 342.
} 
reformasi; republik ini merupakan metamorfosis dari imperium Usmani yang lain sama sekali. Keputusan Mustafa Kemal untuk membentuk Turki sebagai sebuah negara sekuler modern didasarkan kepada kekecewaannya yang sangat mendalam terhadap sistem kekhalifahan sebelumnya. Akhirnya, pada 3 Maret 1924 ia membubarkan institusi yang telah ada sejak masa lalu. ${ }^{24}$ Jadi, sistem pemerintahan Turki di era ini bukan lagi sistem dinasti, tetapi berdasar pada pokok populisme (kerakyatan). Dengan demikian, kedaulatan Turki di masa reformasi diberikan kepada rakyat, dan sistem kekhalifahan sudah tidak diterapkan lagi di Turki.

Walaupun jauh sebelumnya, Islam telah berkembang pesat di Turki, dan memasuki masa reformasi atau masa peralihan dari kekhalifahan ke republik pada dekade 1920-an dan 1930-an Islam semakin mengalami perkembangan signifikan, sebab memang dalam sejarahnya, mayoritas bangsa Turki adalah Muslim. Komposisi penduduk di dalam batas-batas Republik Turki berubah secara dramatis, dan sensus tahun 1927 jumlah penduduk non-Muslim berkurang dari $20 \%$ menjadi $2,6 \%$, dan terus berkurang setelah itu. ${ }^{25}$ Sebaliknya, populasi umat Islam terus berkembang. Pada sensus terakhir di tahun 2000, umat Islam mencapai angka 98\%. ${ }^{26}$ Tentu saja sampai saat ini, tahun 2007 jumlah populasi tersebut tetap bertahan dan bahkan meningkat untuk tidak mengatakan bahwa penduduknya adalah Muslim semua.

Perkembangan Islam dari aspek lain di Turki adalah termasuk dari segi penerapan hukum Islam yang diatur oleh undang-undang negara tersebut. Misalnya, undang-undang keluarga 1924 mengharamkan poligami, menjadikan suami dan istri berkedudukan sama dalam perceraian harus dijatuhkan di pengadilan dengan syarat-syarat tertentu tidak semata-mata hak prerogatif suami. Konstitusi menegakkan hak persamaan wanita dalam pendidikan dan dalam pekerjaan, dan pada

${ }^{24}$ Ajid Thohir, Perkembangan Peradaban Islam di Kawasan Dunia Islam, Cet. I (Jakarta: PT. Raja Grafindo Persada, 2002), 219.

${ }^{25}$ Esposito, The Oxford Encyclopedia, 64.

${ }^{26}$ Iwan Gayo (ed.), Buku Pintar Seri Senior Plus 20 Negara Baru, Cet. VI (Jakarta: Dipayana, 2000), 581. 
tahun 1934 kaum wanita diberi hak untuk dicalonkan dalam pemilihan nasional. ${ }^{27}$ Perkembangan dari segi lain, adalah bahwa di Turki dimasa reformasi, lahir partai-partai Islam yang mewadahi aspirasi umat dan mengontrol jalannya sistem pemerintahan.

Pada dekade 1960-an Turki dilanda konflik partai, dan antara lain sebab konflik tersebut adalah meningkatnya kecenderungan kesadaran politik. Namun demikian, dalam suasana seperti itu Islam tetap berkembang. Aspek perkembangan Islam dan sekaligus kebangkitan Islam lainnya diwakili oleh The National Salvation Party yang juga terbentuk pada dekade 1960-an. Partai ini bukan hanya partai agama (Islam), melainkan juga bermaksud mendirikan kembali negara Islam di Turki sebagaimana di masa sebelumnya. Partai Islam ini menentang kapitalisme dan menyerukan kepada negara untuk menegakkan moral dan keadilan sosial. Semangat moral diserukan partai ini kepada kalangan pengrajin di kota-kota kecil, khususnya di Anatolia tengah dan timur. Partai ini mewakili upaya perlindungan sekelompok kecil borjouis Anatolia dari kesewenang-wenangan pemerintah, dan sekaligus mewakili upaya meningkatkan peranan konstituante terhadap pembangunan ekonomi. Beberapa gerakan Islam di Turki juga menyerukan kepada penduduk perkampungan dan kota-kota kecil yang berpindah ke kota-kota besar dan yang mempertahankan orientasi komunitas kecil dan nilai-nilai lama di lingkungan baru tersebut. ${ }^{28}$ Dengan demikian, perkembangan Islam di Turki harus dipahami kaitannya dengan perubahan dan persaingan politik yang bersifat pluralistik di era reformasi dengan adanya partai-partai politik.

Di samping itu, Islam di negara Turki era kontemporer, tetap saja menjadikan ideologi republik sebagai bentuk sekuler dan kalangan atas berkomitmen terhadap ideologi sekuler tersebut. Kelas terdidik perkotaan dari kalangan atas Turki memandang Islam sebagai simbol kemajuan. Sebaliknya, Demikian pula tradisi sufi-pedalaman tetap bertahan dan loyalitas keislaman masyarakat umum belum pernah tergoyahkan.

\footnotetext{
${ }^{27}$ Lapidus, Sejarah Sosial Umat, 92.

${ }^{28}$ Ibid., 97-98.
} 
Warga Turki senantiasa mengindentifikasi diri sebagai Muslim, bahkan sepanjang periode Kemal mereka senantiasa melaksanakan peribadatan di masjid-masjid dan di beberapa makam para wali.

Perkembangan Islam di Turki di era kontemporer ini merupakan instrumen bagi kebijakan pemerintah. Ia diakui sebagai komponen vital dalam kandungan budaya bangsa dan digalang untuk meningkatkan persatuan nasional, serta mengajarkan secara perlahan-lahan kebajikan kewarganegaan. Shalat, khususya shalat Jumat di masjid-masjid, didukung pelaksanaannya karena ia mengajarkan secara perlahan-lahan disiplin rasa bermasyarakat. Demikian pula puasa membangun ketabahan dan kesabaran, sementara membayar zakat mendorong rasa murah hati seseorang. Materi khutbah Jumat di Turki ditulis secara khusus untuk mengajarkan kepada masyarakat yang pergi ke masjid, terutama yang buta huruf perihal tugas-tugas warga negara. Dikatakan kepada mereka bahwa kewajiban agama meliputi membayar pajak, mengikuti wajib militer, bekerjasama dengan pemerintah, dan menjadi warga negara yang setia serta patuh. Islam di Turki dewasa ini ditampilkan sebagai sebuah agama rasional dan ilmiah. ${ }^{29}$

Demikianlah Islam di Turki dengan aktivitas ritual keislamannya yang terus tersosialisai merupakan simbol perkembangan Islam itu sendiri di negara tersebut. Salah satu pelajaran besar yang amat berharga bagi perkembangan dunia Islam pada umumnya adalah, bahwa Turki telah melakukan reformasi sejarah, yang bermuara pada kenyataan bahwa hampir seluruh penduduknya muslim. Hal tersebut sesungguhnya telah berproses lama sejak masa kerajaaan Turki Usmani sampai masa kini di era kontemporer.

\section{Kesimpulan}

Berdasar pada pemaparan yang telah diuraikan maka disimpulkan bahwa Turki masa sekarang yang dikenal dengan Republik Turki (Republic of Turkey) adalah sebuah negara sekuler yang berawal dari warisan

\footnotetext{
${ }^{29}$ Esposito, The Oxford Encyclopedia, 65.
} 
Kerajaan Turki Usmani. Negara ini sejak dalam bentuk kerajaaan atau dinasti telah mengalami babakan perkembangan sejarah dalam lima periode. Periode pertama, tahun 1299-1402, dimulai dari berdirinya kerajaan. Periode Kedua, tahun 1402-1566, ditandai dengan restorasi kerajaan. Periode ketiga, tahun 1566-1699, ditandai dengan kemampuan Usmani untuk mempertahankan wilayahnya. Periode keempat, tahun 1699-1838, ditandai degan berangsur-angsur surutnya kerajaan kemudian mengalami lagi kemajuan. Periode kelima, tahun 1839-1922, ditandai dengan kebangkitan kultural. Pada periode yang terakhir ini disebut sebagai periode era kontemporer di mana Turki menjadi negara republik, dan tidak lagi sistem pemerintahannya berdasar pada kerajaan, dinasti, atau kekhalifahan sebagaimana yang telah berlangsung berabadabad lamanya.

Dalam sejarah perkembangan Islam di Turki masa lalu, ketika Turki sebagai wilayah kerajaan Islam, Islam sendiri mengalami perkembangan yang sejalan dengan perkembangan. Kemajuan yang dicapai Turki ketika itu antara lain perkembangan wilayah Islam, sosial politik, administrasi pemerintahan, militer, dan umat Islam juga mencapai perkembangan di bidang ekonomi. Demikian seterusnya Turki dan umat Islam berkembang dan maju dalam berbagai bidang sampai Turki memasuki masa reformasi di era kontemporer di mana Turki bukan lagi pemeritahannya berdasarkan pada sistem kerajaan atau dinasti. Sejak diproklamirkan oleh Mustafa Kemal pada 29 Oktober 1923, Turki memasuki masa reformasi atau masa peralihan dari kekhalifahan ke republik. Kemudian, pada dekade 1920-an dan 1930-an Islam semakin mengalami perkembangan yang signifikan di Turki. Komposisi penduduk di dalam batas-batas Republik Turki berubah secara dramatis, dan sensus tahun 1927 jumlah penduduk non-muslim berkurang dari $20 \%$ menjadi $2,6 \%$, dan terus berkurang setelah itu. Sebaliknya populasi umat Islam terus berkembang, dan sensus terakhir pada tahun 2000, umat Islam mencapai angka 98\%. Tentu saja sampai saat ini, tahun 2007 jumlah populasi tersebut tetap bertahan dan bahkan meningkat untuk tidak mengatakan bahwa penduduknya adalah muslim semua. Perkembangan lainnya dapat dilihat dari penerapan hukum Islam yang berjalan dengan baik, dan di sisi 
lain terbentuk partai-partai yang mewadahi aspirasi kepentingan Islam dan kemajuan negara Turki itu sendiri. Lebih dari itu, pelaksanaan ritual keagamaan di Turki tersosialisasi dengan baik tanpa ada hambatan, dan kesemuanya ini merupakan simbol perkembangan Islam di Turki dewasa ini, di era kontemporer.

\section{Daitar Pustaka}

Brockkmann, Carl. History of the Islamic Peoples. London: Routledge \& Kegan Paul, 1982.

Esposito, John L. The Oxford Encyclopedia of the Modern Islamic World. Jilid VI. Oxford: Oxford Univercity Press, 1995.

Gayo, Iwan (ed.). Buku Pintar Seri Senior Plus 20 Negara Baru. Cet. VI. Jakarta: Dipayana, 2000.

Hamka. Sejarah Umat Islam III. Jakarta: Bulan Bintang, 1981.

Hasan, Ibrahim Hasan. Mausu'at al-Tarikh al-Islami V. Kairo: Maktabah al-Nahdhah al-Misriyah, 1967.

Hasan, Ibrahim Hasan. Tarikh al-Islami. Kairo: Maktabah al-Nahdhah al-Misriyah, 1976.

Lapidus, Ira M. Sejarah Sosial Umat Islam. Jakarta: Raja Grafindo Persada, 1999.

Maryam, Siti, et.al. Sejarah Pearadaban Islam dari Masa Klasik hingga Modern. Yogyakarta: LESFI, 2002.

Mughni, A. Syafiq. Sejarah Kebudayaan di Turki. Jakarta: Logos, 1997.

Nasution, Harun. Islam Ditinjau dari Berbagai Aspeknya, Jilid I. Cet. V. Jakarta: UI Press, 1985.

Syalabi, Ahmad. Mausu'ah al-Tarikh al-Islami. Kairo: Maktabah al-Nahdhat al-Mishriyah, tth. 
Thohir, Ajid. Perkembangan Peradaban Islam di Kawasan Dunia Islam. Cet. I. Jakarta: PT. Raja Grafindo Persada, 2002.

Yatim, Badri. Sejarah Peradaban Islam. Cet. VIII. Jakarta: Raja Grafindo Persada, 2002. 